\section{A REFLECTION OF ENGLISH TEACHING}

\author{
Kanchana Prapphal ${ }^{1}$
}

\begin{abstract}
From the Grammar-Translation Method, the Structural Approach to the Communicative Approach, we have gained insights into how to assist our students to acquire and use the target language. It might be concluded from these approaches that "There is no intellectual growth without some reconstruction, some reworking" (Dewey 1938: 64).
\end{abstract}

\section{Introduction}

From the experiences of teaching English to students over decades, language teachers have tried several approaches, methods, and techniques and we have learned about their strengths and weaknesses. From the Grammar-Translation Method, the Structural Approach, and the Communicative Approach, we have gained insights into how to assist our students to acquire and use the target language. The long journey of language teaching and learning seems to be approaching destination. We tend to agree that Communicative Language Teaching may help our students to be able to use the target language for communicative purposes. The empirical evidence from researchers like Bachman and Palmer (1981) support this claim. To be able to use a language one needs the knowledge and skills of "language use" and "language

\footnotetext{
${ }^{1}$ Ph.D., Professor, and Managing Director of Chulalongkorn University--Academic Testing Center.
}

usage" (Hymes, 1972, Widdowson 1978, Canale and Swain 1980)

\section{What are some skills and abilities that language teachers need to have?}

Cambridge ESOL for teachers of English to speakers of other languages has developed "The Teaching Knowledge Test (TKT)". Following are some skills and knowledge they think are important for English teachers:

- Language and the background to teaching and learning.

- Lesson planning and use of resources for language teaching.

- Managing the teaching and learning process.

(http://www.Cambridge ESOL.Org)

The test aims to assess the teachers' abilities in understanding concepts and terms about teaching and learning. Also, the teachers need to be familiar with current theories, approaches and activities related to English language teaching. They should be able to use the activities and assess their usefulness in their own classrooms. In addition, they should be familiar with some of the resources available and keep up with current trends for professional development.

\section{What are the roles of language teachers?}

The idea of "focus on the learner" suggested by Richards and Oller (1975) greatly changed the roles of language teachers in their classrooms. The teacher can no longer be only a lecturer in a language class. We have to take other roles like materials adaptors, facilitators, consultants, and evaluators. In cooperative 
learning, the teacher must know management techniques. He or she has to understand five principles underlying learner contribution in an external syllabus: 1) learner commitment, 2) learners as materials writers and collaborators, 3) learners as problem solvers, 4) learners as knowers, and 5) learners as evaluators and assessors (Clarke, 1989). In brief, we have to pay more attention to our students and get them involved in the teaching and learning process.

\section{What should language teachers do in the era of globalization?}

The introduction of distance education via Inter-and Intranet Pedagogy also drastically changes the roles of language teachers. We have to equip ourselves with new types of syllabus, materials, tasks and activities, and assessment and evaluation. It requires the training of net teachers and the readiness of the students. Materials for the "global classroom" are unlike the traditional textbooks. Tasks and activities for the net pedagogy require prior preparation and planning to ensure that the objectives of the lessons will be accomplished. To assess student' performance, means of testing and evaluation need to correspond with the nature of teaching. In addition, the attitude and the receptiveness of the teachers and students have to be changed.

To cope in the era of globalization, students can no longer be "spoon-fed." To help them achieve their own objectives and pursue their life-long education, teachers themselves have to change their roles. In the "global classroom" the teacher must be the facilitator who provides comprehensible input a nd g ives feedback to the students' output. The task requires a lot of responsibility, skills, knowledge and devotion because net teachers have to learn about their students' computer background, language abilities as well as their needs and interests, They have to select appropriate language tasks to match the students' linguistic backgrounds, cognitive and academic abilities. Also, teachers have to provide immediate feedback and create co-operation among students.

However, Wagner et al (1996: 3) warned us that the computer cannot replace the teacher or motivate students to learn. They said, "And if you want computers to overcome poor teaching, teaching, overcrowded classrooms or unmotivated students, forget the whole thing." In fact, technology should be viewed as another tool for language teachers. Whether it can provide the greatest benefit for enhancing instruction or not depends on the teacher's attitude, understanding, dedication, and innovative mind.

\section{Can language teachers ignore the use of IT?}

In higher education if one of our goals in language teaching is to prepare our students to be qualified world citizens, the ability to use English and the Internet is one essential quality. This is because our graduates can collaborate and share their knowledge, feelings and beliefs with peers from any corner of the world. This issue of higher education quality was discussed in the World Conference on Higher Education organized by UNESCO.

"Quality also requires that higher education should be characterized by its international dimension: exchange of knowledge, interactive networking, mobility of teachers and students, and international research projects." (Wang and Kim, 2000: 1) 
In terms of assessment and evaluation, new methods of assessing competencies of language use of learners have to be included in the syllabus. B oth process and product assessment and evaluation need to be considered. To reinforce interactive networking, electronic portfolios, teleconferencing, on-line self tests, email writing tasks, etc. should be incorporated in the teaching and learning process.

\section{What about the expectations of stakeholders?}

A Chapter in the Educational Reform Act stated that Thai learners should have global literacy. That is they must know English, be able to use the Internet, and understand cultures of other countries to be qualified as world citizens. Wongboonsin et al. (2003) report the desirable skills, competencies, and qualifications suggested by stakeholders, academicians, and specialists in human resource development:

a. Skills: Thai learners should be equipped with conceptual skills, operating skills, technical skills, management skills, human skills, and communication skills.

b. Competencies: They should have English proficiency, computer literacy, analytical ability, innovation, and critical thinking.

c. Qualifications: They must meet international standards, adopt the attitudes of lifelong learning, and have positive attitudes towards learning and working. In addition, they should be able to work in a team.

Therefore, to help our students, especially at the higher level, to become equipped with the skills that both academic and business sectors require, English skills, computer skills and knowledge of cultures need to be integrated into language courses.

\section{What should we do next?}

We need to adjust ourselves to cope with the fast changing world. To meet the international standard, in designing a language course one must consider the local needs as well as regional and global needs. The information should be drawn from teachers, administrators, students, stakeholders and other parties concerned. For example, Short (2003) proposes the following ESL goals for Pre-K-12 students.

Goal 1: To use English to communicate in social setting.

Goal 2: To use English to achieve academically in all content areas.

Goal 3: To use English in socially and culturally appropriated ways.

In terms of materials development, the materials should be prepared base on the goals a nd objectives o btained form n eeds assessment. Both teaching materials and learning materials should be employed. Also, different types of $m$ aterials such a s texts, newspapers, tapes, CD-Rom, Internet, etc. should be used where appropriate to encourage both learning and acquisition in the classroom and outside the classroom. Methods of teaching have to be adapted. Teachers can supplement their teaching by using IT tasks such as CALL activities, E-mail writing tasks, web-based projects, electronic student portfolios, etc. Choosing appropriate tasks for students, teachers can enhance their students' general proficiency as well as achieve the desirable goals and objectives. However, they should bear in mind that

1. Technology cannot substitute for a good language teacher but it can supplement and facilitate our teaching. 
2. Our responsibility is to help our students to communicate and realize that they are part of the "global village."

In addition, the roles of the teacher and learner will change according to the new teaching paradigm. The teachers have to act as teachers, facilitators, mentors, as well as assessors and evaluators, whereas the student have to be learners, collaborators, problem solvers, thinkers, as well as assessors and evaluators. Different methods using IT such as Intranet pedagogy and Internet pedagogy like web-based teaching, distance education and virtual classrooms may be adopted when there is a lack of language teachers. (See Prapphal 1997, 1998 and 2001 for more details.)

To assist our colleagues to keep up with the current trends in language teaching and learning, in-service training in English language teaching should be conducted. These components must be included in the syllabus:

1. Language Development

2. Current trends in language teaching and learning

3. Effective ways of using teaching and learning materials

4. Methodology in language teaching

5. Assessment and evaluation

To enhance our profession and help our students to meet the expectations of society and the world, we should adopt the attitude that "There is no intellectual growth without some reconstruction, some reworking" (Dewey 1938: 64). Reflecting our weaknesses and strengths and sharing them with peers in ELT can help us solve problems in English teaching. Carrying out action research is another possible way to address specific issues of classroom practice on a small and local scale. Last but not least, being positive in our own career and adopting the attitude of lifelong learning may assist us to reach our common goals.

\section{References}

Bachman, L.F. and Palmer, A.S. 1981. A multitrait-multimethod investigation into the construct validity of six tests of speaking and reading. In A.S. Palmer, P.J.M. Groot, and G.A. Trosper (eds.), The Construct Validation of Tests of Communicative Competence. Washington, D.C.: TESOL.

Canale, M. and Swain, M. 1980. Theoretical bases of communicative approaches to second-language teaching and testing. Applied Linguistics, 1(1).

Clarke, D.F. 1989. Materials adaptation: Why leave it all to the teachers? ELT Journal, 43(2).

Dewey, J. 1938. Art as Experience. New York: Minton, Balch.

Friere, P. 1975. Pedagogy of the oppressed. In M.Golby, J.Greenwald and R. West (eds.), Curriculum Design. London:Croom Helm.

Hymes, D.H. 1972. On communicative competence. In J.B. Pride and J. Holmes (eds.), Sociolinguistics. Harmondsworth: Penguin.

Prapphal, K. 1997. Education technology for TEFL. PASAA, 27.

Prapphal, K. 1998. Self-directed learning through the Internet and Intranet pedagogy: a choice for language teachers. PASAA, 28.

Prapphal, K. 2001. Globalization through distance education via Inter- and Intranet pedagogy. PASAA, 31 .

Richards, J.C. and Oller, J.W. (eds.), 1975 . Focus on the Learner. New York: Newbury House Publishers.

Wagner, B., Gregory, S., Bierck, R., Daniel, M. and Sapers, J. 1996. 
Where computers do work. U.S. News and World Report, Dec. 2.

Wang. Y. and Kim, C-H. (November 2000). Quality assurance, credit transfer and mutual recognition in higher education-Role on Quality Assurance in Higher Education: Standard, Mechanisms and Mutual Recognition. Bangkok, Thailand.

Widdowson, H.G. 1978. Teaching Language as Communication. London: Oxford University Press.

Wongboonsin, K., Khunawat, M., Prapphal, K., Hongladarom, S. Surasiangsung, S. Chowpreecha, S., Bunjerdpong, D. and Opanon-Amata, S. 2003. A study on the future of Thai workforce. National Research Council of Thailand.

http://www.Cambridge

http://www.cal.org/ericcll/digest/0013ESL 